\title{
Critical Success Factors Influencing Adoption and Use of E-government Services by SMEs in the Manufacturing Sector in Kenya
}

\author{
Evans M. Mbeche', George Okeyo ${ }^{2}$, Michael Kimwele ${ }^{3}$ \\ Mr., School of Computing \& Information Technology, Jomo Kenyatta University of Agriculture \& Technology, \\ Nairobi, Kenya ${ }^{1}$ \\ Dr., School of Computing \& Information Technology, Jomo Kenyatta University of Agriculture \& Technology, \\ Nairobi, Kenya ${ }^{2,3}$
}

\begin{abstract}
The world over, e-government is increasingly becoming an important means of delivering public service due to the numerous benefits associated with it. Despite this however, low uptake and use of the available e-government services has been witnessed in many developing countries. This occurrence is being attributed to the fact that existing technology adoption models don't take into consideration the unique setting of developing countries leading to complete failures or partial successes of e-government projects. To address this problem, the research sought to establish the critical success factors that influence Small and Medium Enterprises (SMEs) in the manufacturing sector in Kenya to adopt and use e-government services. The study findings are intended to help designers, developers and implementers of e-government projects or G2B platform designers recognize strategic areas of focus that will ensure increased uptake and use of e-government services. To realize the main objective of this study, an exploratory approach using a descriptive survey design was used. Primary data was collected using a structured questionnaire and analyzed using statistical package for social science (S.P.S.S). From the findings of the survey conducted from a sample of 124 SMEs, usefulness, ease of use, quality of the website, government regulations and incentives, organization competitiveness due to use of e-government services, faster broadband connectivity, affordable connectivity, network security and data protection and e-government awareness/training were found to be the most critical success factors that influence the adoption and use of e-government services by SMEs.
\end{abstract}

Keywords: E-government, E-government Adoption and Use, E-government Services, Small and Medium Enterprises.

\section{INTRODUCTION}

\section{A. Background Information}

Governments all over the world from developed to developing countries have well received the idea of e-government because they consider it as the most effective and efficient way of providing customized and collaborative government services utilizing optimal resources (Sharma, 2015 and Guma, 2013). This can be confirmed by the happenings observed around the world in the past two decades where there has been a move towards adoption and use of electronic government aimed at introducing radical changes to the old-style of public service delivery (Al-Mamari, Corbitt and Gekara, 2013). Third world countries as well have embraced the idea of e-government to aid them deliver efficient and effective service to its citizens (Ogutu and Irungu, 2013).

Notwithstanding the benefits associated with e-government, some studies have shown that 60 per cent of e-government projects are classified as either complete failures or partial successes (Gartner 2007). The same has been supported by Verdegem and Verleye, (2009) and Weerakkody, Janssen, and Dwivedi, (2011) who through their studies have indicated that most e-government projects have not been successful in many countries. This has been attributed to among other reasons, the fact that existing international e-government development and implementation models are seen to be best suited to conditions in developed countries according to Nabafu and Maiga (2012), who further notes that implementation of e-government projects in economically and technologically transitioning countries like Kenya remains problematic largely due to the gap between the existing e-government implementation models and the local context for these countries. The existing e-government implementation models as observed by Zarei, Ghapanchi, and Sattary, (2008) are mainly focused in developed countries that have more up to date technology than developing countries and have resolved the non-technical issues of public awareness and e-readiness. In this regard therefore, there is in a need for more customized and context-based models for e-government implementation if developing countries are to fully realize the benefits of e-government. This fact is further emphasized by Accenture (as cited in Bernhard and Grundén, 2013) who observes that it is important for countries not to simply try to imitate examples from others but 


\section{IARJSET

instead to use such examples as inspiration whilst being aware of the importance of the local situation when egovernment projects are implemented.

\section{B. The Problem Statement}

The largest portions of studies on adoption of e-government so far are mostly being carried out in developed countries. Studies by Carter and Weerakkody, (2008); Wang and Shih, (2009); Schaupp, Carter, and McBride, (2010); Il, Seongtae and Myung, (2010) and Gauld, Goldfinch, and Horsburgh, (2010) have revealed that a largest percentage of published studies have been conducted in industrialized countries. The existing adoption frameworks as a result, may not be appropriate for developing countries in Africa like Kenya that are implementing e-government initiatives because they clearly have social and cultural biases according to Mundy and Musa, (2010). The fact that governments around the world do not understand and recognize the distinctive factors that influence e-government adoption (Ahmad, Markkula, and Oivo, 2013) therefore, has been linked by researchers: Belanger and Carter, (2008); Gupta, Dasgupta, and Gupta, (2008); and Kumar, Mukerji, Butt and Persaud, (2007) to cause low-level adoption of e-government services by their citizens. The aspect of adoption and use as pointed out by Yonazi, Sol, and Boonstra, (2010) in their study is a very key pointer of an effective e-government initiative. Similar opinions have been made by Lili, (2009) that the realization of any e-government initiative goals can primarily be measured by its capacity to provide quality service to its intended users and their continued usage. Therefore, the definite way of achieving remarkable outcomes of egovernment initiatives in developing countries like Kenya is through incorporation of a strategy cognizant of the local environment in its design, development and implementation. This will ensure that the local situation which affects adoption and use such as the literacy levels of the people, likelihood of access to ICTs, computer literacy, among other requirements are taken into consideration (Bwalya, Plessis, and Rensleigh, 2014).

\section{Justification}

Most studies conducted on e-government have ignored the contextual factors unique to developing countries which also have a huge influence on adoption and use of e-government services. In Kenyan context for instance, there is no research that has been conducted seeking to explore the behavioural intention by SMEs in the manufacturing sector to adopt and use e-government services. Therefore lack of knowledge about adoption pattern and diffusion of egovernment services among SMEs in Kenya is another reason that necessitated the study. The study is critical at a time when the performance of SMEs in the manufacturing sector has been unsatisfactory over the past seven years with a mere manufacturing growth rate of 3.1 percent which has significantly trailed the overall economic growth (World Bank Group, 2014). The findings of the study can be utilised by government policy makers, designers and implementers of e-government projects targeting government agencies supporting these SMEs. This will in turn result in promoting service delivery of these agencies supporting SMEs in the manufacturing sector.

\section{Research Objectives}

The study intended to meet the following specific objectives:

i) Establish the current status of e-government services adoption and use by SMEs in the manufacturing sector in Kenya.

ii) Establish the critical success factors influencing adoption and use of e-government services by SMEs in the manufacturing sector in Kenya.

By meeting these objectives, the contribution of this research to the arena of e-government will be establishment of the current adoption status and use of e-government among the SMEs in the manufacturing sector in Kenya. Additionally, the critical success factors influencing the adoption and use of e-government services by these SMEs established in this study can be utilized in the development of contextual based e-government adoption frameworks.

\section{METHODOLOGY}

\section{A. Research Design}

This study adopted an exploratory approach using a descriptive survey design. This research design was considered appropriate for this study because as noted by Borg, Gall and Gall (2003), descriptive survey research is anticipated to produce statistical information about the aspects of the research concern (e-government adoption and use in this case) that may draw the attention of policy makers and SMEs. Exploration was also necessary as well since the area under study was new and a researcher needed to do an exploration to learn something about e-government adoption and use by SMEs in the manufacturing sector in Kenya (Cooper and Schindler, 2003).

\section{B. Target Population of the Study}

This study focused on manufacturing SMEs in Nairobi County and its environs that included Athi River (Machakos County), Ruiru (Kiambu County), and Limuru (Kiambu County). According to the data obtained from the Ministry of Industrialization and Enterprise Development and The Kenya Association of Manufacturers reports, 2,120 


\section{IARJSET

manufacturing SMEs are formally registered. About $58.3 \%$ of these manufacturing SMEs (i.e. 1,236) are found in Nairobi and its environs. Using the International Standard Industrial Classification, the SMEs from Nairobi and its environs were categorised into: agro-based (582 enterprises), chemical and mining (300 enterprises) and finally engineering and construction (354 enterprises) sub-sectors.

\section{C. $\quad$ Sample Size}

Ten percent (10\%) of 1,236 SMEs considered in this study i.e 124 SMEs was adequate and representative of the population under study (Gay, 1981). The population of size $\mathrm{N}=1,236$ was divided into three strata of size $\mathrm{N} 1=300, \mathrm{~N} 2$ $=354$ and N3 $=582$. Sizes of the samples from unrelated strata were kept proportional to the sizes of the strata by means of proportional stratification sampling technique. Precisely speaking, if $\mathrm{P}$ denotes the proportion of population included in stratum $i$, and $n$ denotes the total sample size, the number of elements selected from stratum $i=n . P_{i}$. The number of SMEs selected from each stratum was as shown in table 1 below.

TABLE 1 SAMPLE SIZE FOR THE STUDY

\begin{tabular}{|l|l|l|}
\hline Type of manufacturing industry & $\begin{array}{l}\text { Number of manufacturing } \\
\text { industries in each sub-sector }(\mathbf{X})\end{array}$ & $\begin{array}{l}\text { Sample sizes for the different } \\
\text { strata } \mathbf{i}=\mathbf{n . P}_{\mathbf{i}}\end{array}$ \\
\hline Chemical and mining sub-sector & 300 & 30 \\
\hline Engineering and construction sub-sector & 354 & 36 \\
\hline Agro-based sub sector & 582 & 58 \\
\hline Total & 124 \\
\hline
\end{tabular}

\section{Research instruments}

The primary data collection instrument in this study was a structured questionnaire because, they were simple to administer and relatively inexpensive to analyse considering the resource constraints. The various questions in the research instrument sought to get views of respondents on issues the researcher considered valuable in meeting the objectives of the study. The Likert-scaled questions which have been used in previous innovation adoption studies were used (Molla and Licker, 2005).

\section{E. Data Collection Procedures}

To identify the critical success factors promoting adoption of e-government services by SMEs in the manufacturing sector, the study through a questionnaire subjected a list factors that influenced the adoption and use of technology to respondents for feedback. The factors that influence adoption which were adapted from similar studies and from various technology adoption models included: 1) Usefulness, 2) Ease of use, 3) Web-design quality, 4) Size of organization, 5) Top management support, 6) Organizational competence, 7) Government regulations and incentives, 8) Technology support and infrastructure and 9) Competitive pressure. On the other hand, the factors that influence continued use of e-government services also adapted from similar studies and adoption models included: 1) Faster broadband network connectivity 2) More affordable connectivity 3) Increased network security and data protection 4) Greater range of the latest ICT devices and platforms 5) More affordable devices 6) Greater interoperability of ICT devices and platforms across all government departments 7) More local content on government websites 8) More interactive applications and 9) Increased awareness of public about ICT usage in the context of e-government. The respondents selected for this study were top IT experts because they were considered to be more knowledgeable about the organization's ICT capabilities and practices and the fact that they tend to have more knowledge on how to measure constructs under investigation as determinants influencing the adoption of e-government.

\section{F. Data Processing and Analysis}

The researcher analysed the findings from the respondents to determine their views on the various issues that were raised to them in the questionnaire using statistical package for social sciences (SPSS) version 17.0. Appropriate statistical methods were applied on the data to get the results.

\section{FINDINGS AND DISCUSSION}

\section{A. Research Findings}

In line with the study objectives, different questions were presented to respondents to get their views. First, the researcher sought to find out the current status of e-government services adoption and use by SMEs in the manufacturing sector. To achieve this objective, specific questions on this matter were presented to respondents for their feedback. On the issue on how frequently respondents access government services online, findings indicated that $51.2 \%$ occasionally access government services online, $39 \%$ always access government services online and $9.8 \%$ rarely access government services online (table 2). 
TABLE 2 HOW OFTEN THE RESPONDENT ACCESSES PUBLIC SERVICES AVAILABLE ONLINE

\begin{tabular}{|l|l|l|}
\hline How often the respondents accesses public services online & Frequency & Percent \\
\hline Always & 32 & 39.0 \\
\hline Occasionally & 42 & 51.2 \\
\hline Rarely & 8 & 9.8 \\
\hline Total & 82 & 100.0 \\
\hline
\end{tabular}

Concerning the extent respondents were aware of the available e-government services, the survey results as summarized in tables 3 indicated that respondents were fully aware of online service of filing tax returns with a mean of 1.39. On the other hand, respondents were moderately aware of e-procurement system, online registration of business and name search, and online access of government datasets \& information with means of 1.63, 2.18, and 2.26 respectively. When asked to list any other service that they were aware of apart from the ones listed, no respondent indicated to be aware of any other service.

TABLE 3 RESPONSE RATE ON EXTENT OF AWARENESS OF AVAILABLE E-GOVERNMENT SERVICES

\begin{tabular}{|l|c|c|c|c|c|c|c|}
\hline \multirow{2}{*}{ E-government Service } & \multicolumn{6}{|c|}{ Response rate on extent of awareness of available e-government services } \\
\cline { 2 - 8 } & $\begin{array}{c}\text { Not aware } \\
\text { at all }\end{array}$ & $\begin{array}{c}\text { Slightly } \\
\text { aware }\end{array}$ & $\begin{array}{c}\text { Somewhat } \\
\text { aware }\end{array}$ & $\begin{array}{c}\text { Moderately } \\
\text { aware }\end{array}$ & $\begin{array}{c}\text { Fully } \\
\text { aware }\end{array}$ & Total & Mean \\
\hline E-procurement system & $1(1.2 \%)$ & $4(4.9 \%)$ & $8(9.8 \%)$ & $20(24.4 \%)$ & $49(59.8 \%)$ & $82(100 \%)$ & 1.63 \\
\hline $\begin{array}{l}\text { On-line business license \& } \\
\text { permit application }\end{array}$ & $15(18.3 \%)$ & $7(8.5 \%)$ & $9(11 \%)$ & $26(31.7 \%)$ & $25(30.5 \%)$ & $82(100 \%)$ & 2.52 \\
\hline Filing tax returns on-line & - & - & $3(3.7 \%)$ & $26(31.7 \%)$ & $53(64.6 \%)$ & $82(100 \%)$ & 1.39 \\
\hline $\begin{array}{l}\text { On-line access of government } \\
\text { datasets \& information }\end{array}$ & $2(2.4 \%)$ & $1(1.2 \%)$ & $23(28 \%)$ & $46(56.1 \%)$ & $10(12.2 \%)$ & $82(100 \%)$ & 2.26 \\
\hline $\begin{array}{l}\text { On-line registration of business } \\
\text { and name search }\end{array}$ & $4(4.9 \%)$ & $6(7.3 \%)$ & $9(11 \%)$ & $45(54.9 \%)$ & $18(22 \%)$ & $82(100 \%)$ & 2.18 \\
\hline $\begin{array}{l}\text { Extent of awareness of any other } \\
\text { service apart from those listed }\end{array}$ & - & - & - & - & - & - & - \\
\hline
\end{tabular}

The study sought to find out how often respondents use the available e-government services and the results obtained as summarized in table 4 show that online tax filing service had a mean of 1.3 , implying that respondents always used the service. On the other hand, e-procurement system, on-line business license \& permit application service, on-line access of government datasets \& information, and on-line registration of business and name search had means of 1.63, 1.96, 2.3 and 2.01 respectively implying that the services were occasionally used by respondents.

\section{TABLE 4 RESPONSE RATE ON HOW OFTEN ORGANIZATIONS USE AVAILABLE E-GOVERNMENT SERVICES}

\begin{tabular}{|l|c|c|c|c|c|c|c|}
\hline \multirow{2}{*}{$\begin{array}{l}\text { Available e-government } \\
\text { Services }\end{array}$} & \multicolumn{6}{|c|}{ Response rate on how often organizations use available e-government services } \\
\cline { 2 - 8 } & Always & Occasionally & Rarely & Never & I don't Know & Total & Mean \\
\hline E-procurement system & $47(57.3 \%)$ & $25(30.5 \%)$ & $3(3.7 \%)$ & $7(8.5 \%)$ & - & $82(100 \%)$ & 1.63 \\
\hline $\begin{array}{l}\text { On-line business license \& } \\
\text { permit application }\end{array}$ & $18(22 \%)$ & $49(59.8 \%)$ & $15(18.3 \%)$ & - & - & $82(100 \%)$ & 1.96 \\
\hline Filing tax returns on-line & $64(78 \%)$ & $14(17.1 \%)$ & $4(4.9 \%)$ & - & - & $82(100 \%)$ & 1.27 \\
\hline $\begin{array}{l}\text { On-line access of government } \\
\text { datasets \& information }\end{array}$ & $4(4.9 \%)$ & $51(62.2 \%)$ & $25(30.5 \%)$ & $2(2.41 \%)$ & - & $82(100 \%)$ & 2.30 \\
\hline $\begin{array}{l}\text { On-line registration of } \\
\text { business and name search }\end{array}$ & $10(12.2 \%)$ & $61(74.4 \%)$ & $11(13.4 \%)$ & - & - & $82(100 \%)$ & 2.01 \\
\hline Any other & - & - & - & - & - & - & - \\
\hline
\end{tabular}


Concerning the factors that promote wide-scale usage of e-government services by SMEs in the manufacturing sector, the survey results obtained indicated that respondents strongly agreed that faster broadband network connectivity and affordable connectivity promote wide-scale usage of e-government services with means of 1.44 and 1.50 respectively.

On the other hand respondents agreed that increased network security, availability of latest ICT devices \& platforms, availability of affordable devices, device \& platform interoperability, availability of local content in website, interactivity of web application and increased public awareness of e-government promote its usage promote wide-scale usage of e-government services with means of $2.01,2.18,2.23,2.38,2.44$ and 1.89 respectively.

The results are summarised in table 5 below.

TABLE 5 EXTENT OF AGREEMENT ON THE FACTORS THAT PROMOTE WIDE-SCALE USAGE OF EGOVERNMENT SERVICES BY SMES IN THE MANUFACTURING SECTOR

\begin{tabular}{|l|c|c|c|c|c|c|c|}
\hline \multirow{2}{*}{$\begin{array}{l}\text { Factors promoting wide-scale usage } \\
\text { of e-government by SMEs }\end{array}$} & \multicolumn{5}{|c|}{$\begin{array}{c}\text { Response rate on the factors that promote wide-scale usage of e- } \\
\text { government services by SMEs in the manufacturing sector }\end{array}$} \\
\cline { 2 - 8 } & $\begin{array}{l}\text { Strongly } \\
\text { Disagree }\end{array}$ & Disagree & Neutral & Agree & $\begin{array}{c}\text { Strongly } \\
\text { Agree }\end{array}$ & Total & Mean \\
\hline $\begin{array}{l}\text { Extent to which faster broadband } \\
\text { network connectivity promote e- } \\
\text { government usage }\end{array}$ & - & - & $1(1.2 \%)$ & $34(41.5 \%)$ & $47(57.3 \%)$ & $82(100 \%)$ & 1.44 \\
\hline $\begin{array}{l}\text { Extent to which affordable } \\
\text { connectivity promote e-government } \\
\text { usage }\end{array}$ & - & - & $1(1.2 \%)$ & $40(48.8 \%)$ & $41(50 \%)$ & $82(100 \%)$ & 1.50 \\
\hline $\begin{array}{l}\text { Extent to which increased network } \\
\text { security promote wide-scale e- } \\
\text { government usage }\end{array}$ & - & - & $15(18.3 \%)$ & $53(64.6 \%)$ & $14(17.1 \%)$ & $82(100 \%)$ & 2.01 \\
\hline $\begin{array}{l}\text { Extent to which range of latest ICT } \\
\text { devices \& platforms promote e- } \\
\text { government usage }\end{array}$ & - & - & $27(32.9 \%)$ & $43(52.4 \%)$ & $12(14.6 \%)$ & $82(100 \%)$ & 2.18 \\
\hline $\begin{array}{l}\text { Extent to which availability of } \\
\text { affordable devices promote wide- } \\
\text { scale e-government usage }\end{array}$ & - & - & $27(32.9 \%)$ & $51(62.2 \%)$ & $4(4.9 \%)$ & $82(100 \%)$ & 2.28 \\
\hline $\begin{array}{l}\text { Extent to which device \& platform } \\
\text { interoperability promote wide-scale e- } \\
\text { government usage }\end{array}$ & - & - & $19(23.2 \%)$ & $63(76.8 \%)$ & - & $82(100 \%)$ & 2.23 \\
\hline $\begin{array}{l}\text { Extent to which more local content in } \\
\text { website promote wide-scale e- } \\
\text { government usage }\end{array}$ & - & - & $33(40.2 \%)$ & $47(57.3 \%)$ & $2(2.4 \%)$ & $82(100 \%)$ & 2.38 \\
\hline $\begin{array}{l}\text { Extent to which interactive web } \\
\text { application promote wide-scale e- } \\
\text { government usage }\end{array}$ & - & - & $42(51.2 \%)$ & $34(41.5 \%)$ & $6(7.3 \%)$ & $82(100 \%)$ & 2.44 \\
\hline $\begin{array}{l}\text { Extent to which increased public } \\
\text { awareness of e-government promote } \\
\text { its usage }\end{array}$ & - & - & $1(1.2 \%)$ & $51(62.2 \%)$ & $30(36.6 \%)$ & $82(100 \%)$ & 1.65 \\
\hline $\begin{array}{l}\text { Any other factor that promote wide- } \\
\text { scale usage of e-government }\end{array}$ & - & - & - & - & - & - & - \\
\hline
\end{tabular}

The researcher also sought to find out from respondents the factors that influenced them to adopt e-government services. This information was gathered by listing for respondents some of the factors known to influence the adoption of technologies and also giving them an opportunity to give any other factors they felt influenced them to adopt egovernment services.

From the survey findings summarised in table 6 below, usefulness, ease of use, government regulations and incentives and the fact whether the use of e-government services will promote the company's competitiveness were the main 
factors respondents strongly agreed to influence them to adopt e-government services with means of $1.29,1.20,1.24$, and 1.30 respectively. Respondents also agreed that quality of the website through which the e-government services are delivered, support from the top management, organization's capability to use e-government services, and technology support and infrastructure influences the adoption of e-government services.

Their means were 1.62, 2.20, 2.07 and 1.87 respectively. Regarding whether the size of the organization has influence on the adoption of technologies, the results revealed that this factor does not have a significant influence on the adoption of e-government among the SMEs with a mean of 3.20.

\section{TABLE 6 RESPONSE RATE ON THE FACTORS THAT INFLUENCE ADOPTION OF E-GOVERNMENT SERVICES BY SMES IN THE MANUFACTURING SECTOR}

\begin{tabular}{|c|c|c|c|c|c|c|c|}
\hline \multirow{2}{*}{$\begin{array}{l}\text { Factors that influence adoption } \\
\text { of e-government services by } \\
\text { SMEs }\end{array}$} & \multicolumn{7}{|c|}{$\begin{array}{c}\text { Response rate on the factors that influence adoption of e-government } \\
\text { services by SMEs in the manufacturing sector }\end{array}$} \\
\hline & $\begin{array}{l}\text { Strongly } \\
\text { Disagree }\end{array}$ & Disagree & Neutral & Agree & $\begin{array}{l}\text { Strongly } \\
\text { Agree }\end{array}$ & Total & Mean \\
\hline $\begin{array}{l}\text { Extent of agreement whether } \\
\text { usefulness influences adoption of } \\
\text { e-government services }\end{array}$ & - & - & - & $24(29.3 \%)$ & $58(70.7 \%)$ & $82(100 \%)$ & 1.29 \\
\hline $\begin{array}{l}\text { Extent of agreement whether ease } \\
\text { of use influences adoption of e- } \\
\text { government services }\end{array}$ & - & - & $1(1.2 \%)$ & $14(17.1 \%)$ & $67(81.7 \%)$ & $82(100 \%)$ & 1.20 \\
\hline $\begin{array}{l}\text { Extent of agreement whether } \\
\text { quality of website influences } \\
\text { adoption of e-government services }\end{array}$ & - & - & - & $51(62.2 \%)$ & $31(37.8 \%)$ & $82(100 \%)$ & 1.62 \\
\hline $\begin{array}{l}\text { Extent of agreement whether } \\
\text { organization size influences } \\
\text { adoption of e-government services }\end{array}$ & - & $\begin{array}{c}28(34.1 \\
\%)\end{array}$ & $\begin{array}{l}42(51.2 \\
\%)\end{array}$ & $12(14.6 \%)$ & - & $82(100 \%)$ & 3.20 \\
\hline $\begin{array}{l}\text { Extent of agreement whether top } \\
\text { management support influences } \\
\text { adoption of e-government services }\end{array}$ & - & $1(1.2 \%)$ & $\begin{array}{c}19(23.2 \\
\%)\end{array}$ & $57(69.5 \%)$ & $5(6.1 \%)$ & $82(100 \%)$ & 2.20 \\
\hline $\begin{array}{l}\text { Extent of agreement whether } \\
\text { organization capability to use e- } \\
\text { government services influences } \\
\text { adoption of e-government services }\end{array}$ & - & - & $\begin{array}{c}14(17.1 \\
\%)\end{array}$ & $60(73.2 \%)$ & $8(9.8 \%)$ & $82(100 \%)$ & 2.07 \\
\hline $\begin{array}{l}\text { Extent of agreement whether } \\
\text { government regulations \& } \\
\text { incentives influences adoption of } \\
\text { e-government services }\end{array}$ & - & - & - & $20(24.4 \%)$ & $62(75.6 \%)$ & $82(100 \%)$ & 1.24 \\
\hline $\begin{array}{l}\text { Extent of agreement whether } \\
\text { technology support \& } \\
\text { infrastructure influences adoption } \\
\text { of e-government services }\end{array}$ & - & - & $5(6.1 \%)$ & $61(74.4 \%)$ & $16(19.5 \%)$ & $82(100 \%)$ & 1.87 \\
\hline $\begin{array}{l}\text { Agreement whether use of e- } \\
\text { government services promotes } \\
\text { organization competitiveness } \\
\text { influences adoption of e- } \\
\text { government services }\end{array}$ & - & - & - & $25(30.5 \%)$ & $57(69.5 \%)$ & $82(100 \%)$ & 1.30 \\
\hline $\begin{array}{l}\text { Any other factor that promote } \\
\text { adoption of e-government }\end{array}$ & - & - & - & - & - & - & - \\
\hline
\end{tabular}

In identifying the critical factors promoting adoption and wide-scale usage of e-government services, the researcher developed a measure to filter the research findings and identify the critical factors. The same measure was used in a similar study by Watuthu, (2015). The results of the measure are as summarized in tables 7 and 8 below. 
TABLE 7 FACTORS THAT PROMOTE THE WIDE-SCALE USAGE OF E-GOVERNMENT SERVICES BY SMES IN THE MANUFACTURING SECTOR

\begin{tabular}{|l|c|}
\hline \multicolumn{1}{|c|}{ Factor } & Mean on level of agreement \\
\hline Faster broadband network connectivity & 1.44 \\
\hline More affordable connectivity & 1.50 \\
\hline Increased network security and data protection & 2.01 \\
\hline Greater range of the latest ICT devices and platforms & 2.18 \\
\hline More affordable devices & 2.28 \\
\hline $\begin{array}{l}\text { Greater interoperability of ICT devices and platforms across all government } \\
\text { departments }\end{array}$ & 2.23 \\
\hline More local content on government websites & 2.38 \\
\hline More interactive applications & 2.44 \\
\hline Increased awareness of public about ICT usage in the context of e-Government & 1.89 \\
\hline Total & 18.35 \\
\hline
\end{tabular}

Mean $\quad=\frac{\sum x}{N}=18.35 / 9=2.04$

The mean of 2.04 was used as the threshold for responses used to identify the critical factors that promote the widescale usage of e-government services by SMEs in the manufacturing sector. The response with a mean equal or less than 2.04 was considered a critical factor. Using this set criterion, the factors that promote wide-scale usage of egovernment services by SMEs included: faster broadband network connectivity, more affordable connectivity, increased network security and data protection, and increased awareness of public about ICT usage in the context of egovernment Factor analysis results of elements that promote the wide-scale usage of e-government services by SMEs in the manufacturing sector indicated that the factors above had a higher loading of .702, .645, .642 and .632 respectively.

TABLE 8 FACTORS THAT PROMOTE ADOPTION OF E-GOVERNMENT SERVICES BY SMES IN THE MANUFACTURING SECTOR

\begin{tabular}{|l|c|}
\hline \multicolumn{1}{|c|}{ Factor } & Mean on level of agreement \\
\hline Usefulness of the e-Government services & 1.5 \\
\hline Ease of use of the e-Government services & 1.32 \\
\hline Quality of the website through which the service is delivered & 1.62 \\
\hline Size of the SME organization & 3.20 \\
\hline The support given by the management of your organization & 2.20 \\
\hline Capability of your organization to use the e-Government services & 2.02 \\
\hline $\begin{array}{l}\text { Government regulations and incentives given to organizations using e- } \\
\text { Government services }\end{array}$ & 1.37 \\
\hline $\begin{array}{l}\text { Technology support infrastructure put in place for those using e-Government } \\
\text { services }\end{array}$ & 1.87 \\
\hline $\begin{array}{l}\text { How the use of e-Government services by your organization will promote its } \\
\text { competitiveness in the market }\end{array}$ & 1.43 \\
\hline Total & $\mathbf{1 6 . 5 3}$ \\
\hline
\end{tabular}

Mean $\frac{=\sum \mathrm{x}}{\mathrm{N}}=16.531 / 9=1.84$

A threshold of 1.84 was used to identify the factors that promote adoption of e-government services by SMEs in the manufacturing sector. Any response from the survey with a mean equal or less than 1.84 was viewed a critical factor. The factors identified by the researcher as critical included the following: usefulness of the e-government services, ease of use of the e-government services, quality of the website through which the service is delivered, government regulations and incentives given to organizations using e-government services, and whether the use of e-government services by organization will promote its competitiveness in the market. Results of factor analysis of elements that promote the wide-scale adoption of e-government services by SMEs in the manufacturing sector showed that the above factors had a higher factor loadings of $.683, .659, .570, .486$ and .681 respectively.

B. Research Findings Discussion

i) Current status of e-government services adoption by SMEs

The views on this subject matter were sought because in order to identify areas that need improvement, understanding how users currently interact with innovations such as e-government is a key step that ensures the improvement 


\section{IARJSET

initiatives appropriately address users' concerns and adds value to their core activities. Concerning how often the SMEs use available e-government services, the findings showed that majority occasionally accessed available e-government services indicating low levels of adoption and use. These findings reveal existence of a number of reasons inhibiting SMEs from adoption and use of e-government services despite the majority (73.17\%) agreeing that they adequately understand the benefits of using e-government. The study further revealed that the awareness levels of available egovernment services varies from one service to another with online filing of tax returns being the most popular service among the SMEs surveyed. This popularity is attributed to the existence of a good legal framework and knowledge creation measures put in place by Kenya Revenue Authority (KRA). In addition, the convenience the online system has created to users has contributed to its popularity. These findings concur with those of Hassan and Lee (2015) who point out that to achieve successful implementation of e-government programs in developing countries, favourable legal frameworks and laws must be in place. A positive correlation was observed between the awareness level of available egovernment services and frequency of usage. The more aware SMEs were aware of a particular e-government service the more frequently they used it.

ii) Factors promoting adoption of e-government services

Views were sought from respondents on this issue to find out the factors that encouraged SMEs to adopt e-government services. The factors which were categorized as the innovation characteristics, environmental, organizational and social factors were presented to respondents to give their feedback on which of these factors greatly influenced them to adopt e-government. The study findings closely compared to those obtained in a study by Looi, (2004) in which perceived benefits, knowledge and skill, trust, competitive pressure, government support and infrastructure were considered significant factors that influenced SMEs in Brunei Darussalam to adopt electronic commerce.

iii) Factors promoting wide-scale usage of e-government services

Even though the provision of e-government services is becoming more and more improved, studies have shown that the use of all of these potential improvements is still below expectations (Kumar et al., 2007). Continued usage of egovernment service by current users is an important dimension of effective e-government services (Sigwejo and Pather, 2016). The results of our studies showed that faster broadband network connectivity, more affordable connectivity, increased network security and data protection, and increased awareness of public about ICT usage in the context of egovernment promote usage of available e-government services by SMEs. These findings concurs with those by McKinnon et al. as cited in Kunstelj, Jukic and Vintar, (2009) and Weerakkody et al. (2016) which showed that reduced cost, time savings and faster response greatly encourages the use of e-government services. Findings of studies by Tassabehji and Elliman, (2006); Cullen and Reilly, (2007); and Weerakkody et al. (2016) likewise reveal that network security and data protection promotes usage of e-government services. Regarding the effects lack of awareness by users about available e-government services, our findings concur with those of AIShihi, (2006) and AGIMO, (2006) who notes that lack of awareness creation campaigns is one of most important barrier to the use of e-government.

\section{CONCLUSION AND FUTURE WORK}

According to the study findings, the rate of uptake and use of e-government services by SMEs in the manufacturing sector in Kenya is very low. This is so regardless of the majority of SMEs (73.17\%) agreeing to have an adequate understanding of the benefits of using e-government. The valid question that should be pursued is how to increase the uptake and usage level of e-government services among the SMEs in the manufacturing sector. First and foremost, efforts should be made to convince current SMEs not using e-government services to embrace e-government, and, of course, retain current users. From the findings discussed above, a positive behavioural intention towards use of egovernment by SMEs can be enhanced by provision of e-government services that are valuable to them in conducting their core businesses, easy to use, delivered through quality website, putting in place favourable government regulations and incentives, and providing e-government services that focus in promoting SMEs' competitiveness in the market. On the other hand, to encourage continued usage of e-government, facilitating conditions that directly influence intention to use, use and reuse, and as a result, user satisfaction should be put in place. The facilitating conditions that SMEs under study considered to be very critical included: faster broadband network connectivity, affordable connectivity, increased network security and data protection, and increased awareness creation and training about ICT usage in the context of e-government. The findings of this study will be very useful to policy makers and implementers of e-government projects with useful information in identifying key priority areas during the planning, designing and implementing of e-government projects or G2B platforms that can guarantee success because the unique factors that influence adoption and continued usage will be taken into consideration.

To better comprehend and improve e-government uptake and use, there is therefore need for further research on egovernment adoption and use by SMEs in other sectors of the economy for comparison purposes and development of a single adoption model for all SMEs from different sectors in Kenya. 


\section{IARJSET \\ Vol. 4, Issue 6, June 2017}

\section{REFERENCES}

[1] AGIMO (2006) Australians' Use of and Satisfaction with E-government Services. Commonwealth of Australia; http://www.finance.gov.au/ publications/use-of-e-government-services-2006/docs/2006_Measurementreport_final.pdf, accessed on 26 May 2017

[2] Ahmad, M.O., Markkula, J. and Oivo, M. (2013). Factors affecting e-government adoption in Pakistan: a citizen's perspective. Transforming Government: People, Process and Policy, 7(2) 225 - 239. Available at: http://dx.doi.org/10.1108/17506161311325378.

[3] Al-Mamari, Q., Corbitt, B., and Gekara, V.O. (2013). E-government adoption in Oman: motivating factors from a government perspective. Transforming Government: People, Process and Policy, (7)2, 199 - 224. Doi: $10.1108 / 17506161311325369$

[4] Alshihi, H. (2006) 'Critical Factors in the Adoption and Diffusion of E-government Initiatives in Oman', PhD dissertation. Victoria University; vuir.vu.edu.au/483/1/AlShihi_PhD.pdf, accessed on 26 May 2017

[5] Belanger, F. and Carter, L. (2008). Trust and risk in e-government adoption. Journal of Strategic Information Systems, 17(2), 165-176.

[6] Bernhard, I. and Grundén, K. (2013). Challenging organizational issues when municipal contact centers are implemented in Sweden. Electronic Journal of e-Government, 11(2), 198-209. Available at www.ejeg.com.

[7] Borg, W. R., Gall, M. D., and Gall, J. P. (2003). Educational Research: An Introduction. (6th edn). New York: Longman Inc.

[8] Bwalya, K.J., Plessis, T.D. and Rensleigh, C. (2014). E-government implementation in Zambia - prospects. Transforming Government: People, Process and Policy, 8(1), 101-130. Doi: 10.1108/TG-01-2013-0002.

[9] Carter, L. and Weerakkody, V. (2008). E-government adoption: a culture comparison. Information Systems Frontiers, 10(4), 473- 482.

[10] Cooper, R.D., and Schindler, P.S. (2003). Business research methods. (8th edn.).New Delhi: Tata McGraw-Hill Edition.

[11] Cullen, R. and Reilly, P. (2007) 'Information Privacy and Trust in Government: A Citizen-based Perspective from New Zealand', in Proceedings of the 40th Annual Hawaii International Conference on System Sciences, Hawaii, Waikoloa, 2007.

[12] Gartner, A. (2007). Majority of e-government initiatives fail or fall short of expectations, Inc's Executive Programs, San Diego, CA.

[13] Gauld, R., Goldfinch, S. and Horsburgh, S. (2010). Do they want it? Do they use it? The 'demand-side' of e-government in Australia and New Zealand. Government Information Quarterly, 27(2), 177-186.

[14] Gay, L. R. (1981). Education Research: competencies for Analysis and application. Charles E. Mairill Publishing Company, Bell, A. and Howell Company. Columbus, Toronto and London. London: Charles E. Mairill Publishing Company.

[15] Guma, P.K. (2013). Public-sector reform, e-government and the search for excellence in Africa: experiences from Uganda. Electronic Journal of e-Government, 11(2), 241-253).

[16] Gupta, B., Dasgupta, S. and Gupta, A. (2008). Adoption of ICT in a government organization in a developing country: an empirical study. Journal of Strategic Information Systems, 17(2), 140-154.

[17] Hassan, M.H. and Lee, J. (2015). Policymakers' perspective towards e-Gov success: A potent technology for attaining Good Governance in Pakistan. Digital Information Processing and Communications (ICDIPC), 2015 Fifth International Conference on, Sierre, pp. 272-281. doi: 10.1109/ICDIPC.2015.7323041

[18] Il, I., Seongtae, H. and Myung, S.K. (2010). An international comparison of technology adoption testing the UTAUT model. Journal of Information \& Management, 48, 1-8.

[19] Kumar, V., Mukerji, B., Butt, I. and Persaud, A. (2007). Factors for successful e-government adoption: a conceptual framework. The Electronic Journal of e-Government, 5(1), 63-76.

[20] Kunstelj, M., Jukic, T. and Vintar, M. (2009). How to fully exploit the results of e-government user surveys: the case of Slovenia. International Review of Administrative Sciences; 75; 117. DOI: 10.1177/0020852308099509 Lili, Q. (2009). A Framework for Perception of Citizen Demand in E-government Services. 2009 International Conference on Information Management, Innovation Management and Industrial Engineering. Xi'an, 2009, pp. 468-471. doi: 10.1109/ICIII.2009.572.

[21] Looi, H. (2004). A model of factors influencing electronic commerce adoption among SMEs in Brunei Darussalam. International Journal of Information Technology,10(1). Retrieved from: http://citeseerx.ist.psu.edu/viewdoc/summary?doi=10.1.1.133.2364

[22] Molla, A., and Licker, P. (2005). E-Commerce adoption in developing countries: a model and instrument. Information and Management, 42(6), 877-899.

[23] Mundy, D. and Musa, B. (2010). Towards a framework for e-government development in Nigeria. Electronic Journal of e-Government, 8(2), 148-161, available online at www.ejeg.com.

[24] Nabafu, R. and Maiga, G. (2012). A model of success factors for implementing local e-government in Uganda. Electronic Journal of eGovernment,10(1), 31-46. Retrieved from www.ejeg.com.

[25] Ogutu J. O. and Irungu J.K. (2013). Citizen-Centric Evaluation Framework for e-Government Systems in Kenya. The Case of Public Service Commission of Kenya Online Recruitment \& Selection System. IST-Africa 2013 Conference Proceedings. Retrieved from www.ISTAfrica.org/Conference2013

[26] Schaupp, L.C., Carter, L. and McBride, M.E. (2010). E-file adoption: a study of US taxpayers intentions. Computers in Human Behavior, $26(4), 636-644$.

[27] Sharma, S.K. (2015). Adoption of e-government services: the role of service quality dimensions and demographic variables. Transforming Government: People, Process and Policy, 9(2). doi: 10.1108/TG-10-2014-0046.

[28] Sigwejo, A. and Pather, S. (2016). A citizen-centric framework for assessing e-government effectiveness. The Electronic Journal of Information Systems in Developing Countries. Vol. 74, 8, p 1-27. Available online at www.ejisdc.org.

[29] Tassabehji, R. and Elliman, T. (2006) 'Generating Citizen Trust in E-government Using a Trust Verification Agent: A Research Note', in Proceedings of the European and Mediterranean. Conference on Information Systems (EMCIS) 2006, 6-7 July 2006, Costa Blanca, Alicante, Spain.

[30] Verdegem, P. and Verleye, G. (2009). User-centred e-government in practice:a comprehensive model for measuring user satisfaction. Government Information Quarterly, 26(3), 487-497.

[31] Wang, Y.S. and Shih, Y.W. (2009). Why do people use information kiosks? A validation of the unified theory of acceptance and use of technology. Government Information Quarterly, 26(1), 158-165.

[32] Watuthu, S.N. (2015). A Framework to Extend COBIT Security Framework to Overcome Confidentiality Threats in Electronic Commerce (Maters Thesis, Jomo Kenyatta University of Agriculture and Technology, Kenya). Available from http://ir.jkuat.ac.ke:8080/browse?type=author\&value=Watuthu\%2C+Simon+ Nderitu Digital Theses database. (Record No. 185877)

[33] Weerakkody, V., Irani, Z., Lee, H., Hindi, N. \& Osman, I. (2016). Are U.K. Citizens Satisfied With E-Government Services? Identifying and Testing Antecedents of Satisfaction, Information Systems Management, 33:4, 331-343, DOI: 10.1080/10580530.2016.1220216.

[34] Weerakkody, V., Janssen, M. and Dwivedi, Y.K. (2011). Transformational change and business process reengineering (BPR): lessons from the British and Dutch public sector. Government Information Quarterly, 28(1), 320-328.

[35] World Bank Group. (2014). Kenya economic update: anchoring high growth, can manufacturing contribute more? (1 $1^{\text {th }}$ ed.).Washington DC, USA: Author

[36] Yonazi, J., Sol, H. and Boonstra, A., (2010). Exploring issues underlying citizen adoption of e-government initiatives in developing countries: the case of Tanzania.Electronic Journal of e-Government, 8(2), 176-188). Available online at www.ejeg.com.

[37] Zarei, B., Ghapanchi, A \& Sattary, B. (2008). Toward national e-government development models for developing countries: a nine stage model. The International Information and Library Review, 40(1), 199-207. 